University of South Florida

DIGITAL COMMONS

Digital Commons @ University of

@ UNIVERSITY OF SOUTH FLORIDA

South Florida

$7-2020$

\title{
DNA Barcoding of Fish Eggs Collected off Northwestern Cuba and Across the Florida Straits Demonstrates Egg Transport by Mesoscale Eddies
}

\author{
Makenzie Kerr \\ University of South Florida, burrowsm@usf.edu \\ Jeremy Browning \\ University of South Florida, jbrowning@mail.usf.edu \\ Eva-Maria Bønnelycke \\ University of South Florida \\ Yingjun Zhang \\ University of South Florida, yingjunzhang@usf.edu \\ Chuanmin $\mathrm{Hu}$ \\ University of South Florida, huc@usf.edu \\ Follow this and additional works at: https://digitalcommons.usf.edu/msc_facpub \\ See next page for additional authors \\ Part of the Life Sciences Commons
}

\section{Scholar Commons Citation}

Kerr, Makenzie; Browning, Jeremy; Bønnelycke, Eva-Maria; Zhang, Yingjun; Hu, Chuanmin; Armenteros, Maickel; Murawski, Steven; Peebles, Ernst B.; and Breitbart, Mya, "DNA Barcoding of Fish Eggs Collected off Northwestern Cuba and Across the Florida Straits Demonstrates Egg Transport by Mesoscale Eddies" (2020). Marine Science Faculty Publications. 1296.

https://digitalcommons.usf.edu/msc_facpub/1296

This Article is brought to you for free and open access by the College of Marine Science at Digital Commons @ University of South Florida. It has been accepted for inclusion in Marine Science Faculty Publications by an authorized administrator of Digital Commons @ University of South Florida. For more information, please contact digitalcommons@usf.edu. 


\section{Authors}

Makenzie Kerr, Jeremy Browning, Eva-Maria Bønnelycke, Yingjun Zhang, Chuanmin Hu, Maickel Armenteros, Steven Murawski, Ernst B. Peebles, and Mya Breitbart 
i. Title: DNA barcoding of fish eggs collected off northwestern Cuba and across the Florida Straits demonstrates egg transport by mesoscale eddies

\section{ii. Running Title: DNA barcoding of fish eggs near Cuba}

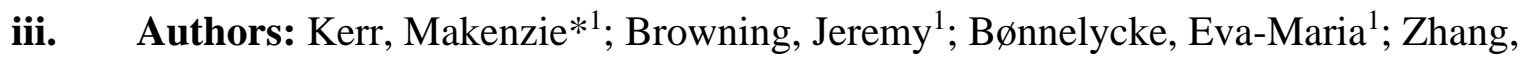
Yingjun $^{1}$; Hu, Chuanmin ${ }^{1}$; Armenteros, Maickel ${ }^{2,3}$; Murawski, Steven ${ }^{1}$; Peebles, Ernst $^{1}$; Breitbart, Mya ${ }^{1}$

*Corresponding author - Makenzie Kerr, burrowsm@usf.edu

iv. 1-College of Marine Science, University of South Florida, Saint Petersburg, Florida

2-Centro de Investigaciones Marinas, Universidad de La Habana, Habana, Cuba

3-Universidad Nacional Autónoma de México, Ciudad de México, México

\section{v. Acknowledgements}

We gratefully acknowledge funds provided by a grant from The Gulf of Mexico Research Initiative/C-IMAGE II (No. SA 15-16) supporting the expedition of the R/V Weatherbird II to Cuba. The captain and crew of the ship provided invaluable logistical support. Additionally, the

Cuban State Department (MINREX) and the U.S. Departments of Commerce, Treasury, and State provided export and import licenses for the expedition, and we are grateful. The collection of samples in Cuban waters was made under the authorization AN(17)/2017 granted by the Centro de Inspección y Control Ambiental (CICA) from the Ministerio de Ciencia, Tecnología y Medioambiente (CITMA) of the República de Cuba. DNA barcoding was supported by grants 4710-1126-02 and 4710-1126-03 from the Florida RESTORE Act Centers of Excellence Program, with oversight by the US Treasury. M.K. was funded by the William T. Hogarth Fellowship in Marine Mammals and the Women in Leadership and Philanthropy Dorothy L. Morgan Endowed Fellowship for Marine Science, and Y.Z. was supported by a NASA student 
24 fellowship (FINESST, 80NSSC19K1358). Additionally, we would like to thank Julie Vecchio 25 for her expert advice.

27 Data Availability Statement:

The sequence data have been deposited into GenBank under the accession numbers MN811696MN812161 (www.ncbi.nlm.nih.gov/genbank), but are still pending.

\section{vi. Abstract and keywords}

32 Keywords: Cuba, genetic, spawning, barcoding, Florida Straits, fish egg, reef-associated Identifying spawning sites for broadcast spawning fish species is a key element of delineating critical habitat for managing and regulating marine fisheries. Genetic barcoding has enabled accurate taxonomic identification of individual fish eggs, overcoming limitations of morphological classification techniques. In this study, planktonic fish eggs were collected at 23 stations along the northwestern coast of Cuba and across the Florida Straits to United States waters. A total of 564 fish eggs were successfully identified to 89 taxa within 30 families, with

39 the majority of taxa being resolved to species. We provide new spawning information for Luvarus imperialis (Louvar), Bothus lunatus (Plate Fish), Eumegistus illustris (Brilliant

41 Pomfret), and other economically important species. Data from most sites supported previously 42 established patterns of eggs from neritic fish species found on continental shelves and oceanic 43 species spawning over deeper waters. However, some sites deviated from this pattern, with eggs 44 from reef-associated fish species detected in the deep waters of the Florida Straits and pelagic 45 species detected in the shallow, continental shelf waters off the coast of northwestern Cuba. 46 Further investigation using satellite imagery revealed the presence of a mesoscale cyclonic eddy, 
47 likely entraining neritic fish eggs and transporting them into the Florida Straits. The technique of

combining DNA-based fish egg identification with remote-sensing hydrodynamics provides an important new tool for assessing the interplay of regional oceanography with fish spawning strategies.

\section{vii. Main text}

\section{Introduction}

Understanding the life cycle of fish species, including their spawning locations and early life history, is necessary for identifying critical habitats and supporting future fisheries management (Claro et al., 2014). Due to the difficulty in accurately identifying fish eggs based on morphology, many studies have inferred spawning locations of a given species based on the presence of larvae (Limouzy-Paris et al., 1994; Peebles \& Tolley, 1988; Sassa et al., 2006). However, fish larvae can be days to months old before capture (Cowen \& Sponaugle, 2009); therefore, using larval-fish collection locations to hindcast spawning locations may result in considerable uncertainty. Variation in pelagic larval duration and larval behaviors, including vertical migration (Vikebø et al., 2007) along with variation in surface-water transport, contribute to this uncertainty. Alternatively, fish eggs are typically only hours old before hatching into larvae, and eggs behave as relatively passive particles once they have floated to surface waters, reducing the error in predicting spawning location using hydrodynamic models (Harada et al., 2015). The only study to directly compare the species composition of fish eggs and larvae from the same location (Terra Ceia Bay, Florida, USA) demonstrated different species in each of these early life stages, weakening the value of using larvae for spawning site prediction (Burghart et al., 2014). 
Broadcast spawning is the most common reproductive strategy among reef fishes

71 (Thresher, 1984), resulting in egg dispersal in the water column, where the majority of eggs float

72 to the surface due to positive buoyancy (Fabra et al., 2005). Identification of drifting fish eggs

73 collected with plankton nets, combined with hydrographic modeling of surface currents, can

74 therefore be used to hindcast spawning locations of fish taxa. Historically, fish eggs have been

75 identified based on color, size of perivitelline space, oil globules, yolk, and shape. But there are

76 very few distinguishable characteristics and continuous ontogenetic changes, which makes visual

77 discrimination among taxa ambiguous (Kawakami et al., 2010). One exception is for clupeoid

78 (anchovy, herring, and sardine) eggs, which are easily distinguished from percomorph (spiny-

79 finned fishes) eggs based on their shape and size. Additionally, some visual features used for

80 identification, including coloration, can be lost during the preservation process (Smith et al.,

81 2005). Previous studies comparing visual identifications of percomorph eggs with results from

82 genetic barcoding have shown that visual identification is unreliable (Larson et al., 2016). In

83 contrast, genetic barcoding of the mitochondrial cytochrome $c$ oxidase I (COI) gene allows for

84 the identification of fish eggs, often to species (Ahern et al., 2018; Burrows et al., 2019; Duke et

85 al., 2018). The Barcode of Life Database (BOLD; http://www.boldsystems.org/) contains

86 reference sequences for over 20,000 ray-finned fish species (Actinopterygii), serving as an

87 excellent community-driven resource for the identification of fish sequences (Ward et al., 2009).

88 Furthermore, DNA barcoding of individual fish eggs allows for a quantitative measure of the

89 relative abundance of eggs contributed by each species, from a given multispecies sample

90 (Burrows et al., 2019).

We used DNA barcoding to determine which broadcast-spawning fish species spawn in

92 Cuban (all stations south of station F6) and United States (U.S.) waters of the southeastern Gulf 
93 of Mexico (GoM). The northwestern Cuba region has a broad continental shelf in the western 94 part (Gulf of Guanahacabibes) and a very narrow shelf in the eastern part (Punta Gobernadora to Habana bay). The continental slope extends from the shelf break ( $35 \mathrm{~m}$ depth) to about $10 \mathrm{~m}$ with a very steep slope, then to about 2000 meters with a gentle slope (Ionin et al., 1977). There

97 are well-developed tropical habitats (e.g., mangrove, seagrass meadows, shallow and mesophotic

98 reefs) supporting over 1,000 fish species or subspecies (Claro et al., 2014). Cuba also has many commercially important finfish species including tunas (e.g., Thunnus atlanticus, Katsuwonus pelamis), Swordfish (Xiphias gladius), snappers (Lutjanidae), grunts (Haemulidae), jacks

101 (Carangidae), and groupers (Serranidae). One experiment in the Florida Straits observed the spawning of Istiophorus platypterus (Sailfish) to study the relationship between physical

103 processes and larval development (Richardson et al., 2009). In another study, the species composition of fish eggs found on and off the continental shelves of the GoM showed a clear

105 delineation of neritic species spawning on the continental shelves, and oceanic species spawning 106 in deeper waters (Burrows et al., 2019). The present study aims to add new spawning 107 information for species in the southeastern GoM. This area has a very steep shelf slope, dynamic 108 physical processes, and acts as the major exit area for the surface circulation of the entire GoM through Florida Straits, making it an interesting study area for observing fish egg distributions.

\section{Methods}

\section{Study Site and Sample Collection}

Planktonic fish eggs were collected at 23 stations across the Florida Straits and along the 113 northwestern coast of Cuba with a $333 \mu \mathrm{m}$ mesh bongo net, towed at the surface for 15 minutes 114 from the RV Weatherbird II (http://www.fio.usf.edu/vessels/rv-weatherbird) in May 2017 (Figure

115 1, Table 1). One of the two bongo net samples was preserved immediately with $30 \%$ isopropanol 
116 and returned to the laboratory ${ }^{1}$. Plankton samples from sites F1-F9, C7, C8, C10, C11, and C14

117 were held in the original preservative (30\% isopropanol) for two months, while sites C1-C6, C9,

118 C12, and C13 were held in the original preservative for over a year. The percomorph eggs were

119 then picked from samples with forceps under a stereomicroscope at 9-108X magnification. Egg

120 density for each site was calculated as the total number of eggs in the sample divided by the

121 volume of water filtered by the plankton net (determined via flowmeter). A subsample of $\geq 96$

122 percomorph eggs from each collection was placed into a glass vial with $50 \%$ isopropanol until

123 DNA extractions were performed on individual eggs.

124

125

126

127

reaction (PCR) tubes, and excess isopropanol removed. DNA extractions were performed using

128 the HotSHOT method (Truett et al., 2000). To lyse the eggs, $50 \mu$ of alkaline lysis buffer (0.2

mM disodium EDTA, 25 mM NaOH, pH 12) were added to each tube and each egg was crushed

130 with a sterile toothpick. All PCR tubes were set in a thermocycler at $95{ }^{\circ} \mathrm{C}$ for 30 minutes and

131 then moved onto ice for three minutes to cool to room temperature. To complete the extraction,

$13250 \mu \mathrm{l}$ of neutralization buffer (40 mM Tris-HCL, $\mathrm{pH}$ ) were added and the samples were

133 vortexed to mix thoroughly.

The PCR technique was used to amplify a portion of the mitochondrial COI gene with the

135 COI-3 universal fish primer cocktail (Ivanova et al., 2007). Each $50 \mu 1$ PCR reaction contained 2

$136 \mu$ of DNA template and final concentrations of $1 \mathrm{X}$ Apex $\mathrm{NH}_{4}$ buffer, $1.5 \mathrm{mM}$ Apex $\mathrm{MgCl}_{2}, 10$

$137 \mu \mathrm{g} / \mu \mathrm{l}$ bovine serum albumin (New England BioLabs Inc.), $0.2 \mu \mathrm{M}$ Apex dNTPs, $0.2 \mu \mathrm{M}$ primer

138 cocktail, 1 U Apex RedTaq ${ }^{\circledR}$ (Genesee Scientific). The thermocycling protocol consisted of 
139 heating to $94{ }^{\circ} \mathrm{C}$ for 2 minutes, 45 cycles of $\left(94{ }^{\circ} \mathrm{C}\right.$ for 30 seconds, $52{ }^{\circ} \mathrm{C}$ for 40 seconds, $72{ }^{\circ} \mathrm{C}$

140 for 1 minute), followed by extension at $72{ }^{\circ} \mathrm{C}$ for 10 minutes. To confirm successful

141 amplification, the PCR products were run on a 1.5\% agarose gel (60 minutes, $120 \mathrm{~V}$ ) and stained

142 with ethidium bromide for visualization. Successful PCR products were sent to TACGen

143 (tacgen.com) for purification and Sanger sequencing using the M13 forward primer (Ivanova et

144 al., 2007). In order to differentiate between certain economically important species that are

145 closely related, a second PCR was performed using the same PCR mixture described above with

146 different primers. Primers L8562 and H9432 were used to differentiate between Thunnus thynnus

147 and Katsuwonus pelamis (72 eggs), with the following thermocycler conditions: 2 minutes at 94

$148{ }^{\circ} \mathrm{C}$, followed by 45 cycles of $\left(94^{\circ} \mathrm{C}\right.$ for 30 seconds, $50{ }^{\circ} \mathrm{C}$ for 40 seconds, $72{ }^{\circ} \mathrm{C}$ for 1.5

149 minutes), and 10 minutes at $72{ }^{\circ} \mathrm{C}$ (Chow \& Inoue, 1993). Primers LCOI 121 and HCOI 1199

150 were used to differentiate between Scomberomorus cavalla and Acanthocybium solandri (five

151 eggs), with the following thermocycler conditions: 2 minutes at $94{ }^{\circ} \mathrm{C}$, followed by 45 cycles of

152 (94 ${ }^{\circ} \mathrm{C}$ for 30 seconds, $57^{\circ} \mathrm{C}$ for 40 seconds, $72{ }^{\circ} \mathrm{C}$ for 2 minutes), and 10 minutes at $72{ }^{\circ} \mathrm{C}$

153 (Paine et al., 2007). All PCR products were cleaned with a Zymo Clean \& Concentrator -25 kit

154 and sent for bidirectional Sanger sequencing at TACGen (tacgen.com).

155

156

\section{Data Analysis}

157

Sequencher 5.3 (Genecodes) was used to trim the DNA sequences for quality. Poor

158 quality sequences were removed from further processing and considered unidentified. Trimmed

159 sequences were compared to the species-level records on the Barcode of Life Database (BOLD;

160 http://www.boldsystems.org/) for assignment to the lowest taxonomic level possible. If there was

161 no match in BOLD, sequences were compared to the GenBank nucleotide database using the 
162 Basic Local Alignment Search Tool (BLAST; https://blast.ncbi.nlm.nih.gov/Blast.cgi).

163 Sequences with less than 97\% identity to the GenBank database were considered unidentified.

164 Information on fish common names, habitat, and economic importance was taken from FishBase 165 (Froese, 2019).

166

167

168

169

170

171

172

173

174

175

176

177

178

179

180

181

182

183

184

\section{Satellite Imagery}

To provide context for the results, satellite imagery from the closest possible dates were examined for the region of interest. MODIS/A chlorophyll $a$ data from May 10, 2017 were obtained from NASA (https://oceancolor.gsfc.nasa.gov) (Figure 2a). These 1-km resolution data were generated using the NASA standard algorithms for atmospheric correction and bio-optical inversion and were used in this study to visualize color patterns to infer circulations. The geostrophic velocity anomaly data with a spatial resolution of $1 / 4^{\circ} \times 1 / 4^{\circ}$ for May 24,2017

(Figure 2b) and April 10, 2017 through July 25, 2017 (Supplemental Animation) were derived from the altimetry sea level anomalies and distributed by Copernicus Marine Environment Monitoring Service (CMEMS; http://marine.copernicus.eu/).

\section{Results}

Fish Eggs

The density of fish eggs at stations along the cruise transect ranged from 0.02 to 9.44 eggs $\mathrm{m}^{-3}$ (Table 1). A total of 1562 eggs from 23 sites were processed for DNA barcoding. Due to poor sample preservation (see Discussion), a large number of these eggs did not yield PCR products $(n=832)$ or high quality sequences $(n=101)$. In addition, 65 sequences were most similar to invertebrates or had $<97 \%$ identity to sequences in the BOLD or GenBank databases. 
185 The 564 fish eggs successfully identified included 89 taxa within 30 families. Fifty-eight of the

186 taxa were identified to species level, 21 to genus, and the remaining 10 to family or higher.

Of the 89 fish taxa identified, 51 were reef-associated. Some of the most frequently encountered reef-associated species (Supplemental Table 1) included Acanthurus spp. (surgeonfishes), Haemulon spp. (grunts), Halichoeres spp. (wrasses), Lactophrys spp. (trunkfishes), Lutjanus spp. (snappers), Ocyurus chrysurus (Yellowtail Snapper), Sparisoma viride (Stoplight Parrotfish), Syacium papillosum (Dusky Flounder), Synodus spp. (lizardfishes), Thalassoma bifasciatum (Bluehead Wrasse), and Xyrichtys novacula (Pearly Razorfish). Some of the most frequently detected oceanic species (Supplemental Table 1) included Decapterus sp. (scad), Katsuwonus pelamis (Skipjack Tuna), Psenes spp. (driftfish), and Thunnus spp. (tunas). In general, reef-associated species dominated the fish eggs detected in nearshore waters, while pelagic species were found in deeper waters (Figure 1). A notable exception to this trend was station F7, which had eggs from a few reef-associated species in an area of deep water (667 m), leading to further investigation of oceanographic conditions.

\section{Oceanographic Conditions}

Satellite imagery was examined to determine if any physical oceanographic features were associated with site F7, which yielded a mixture of eggs from reef-associated and pelagic species, despite being over deep waters. MODIS chlorophyll $a$ concentration (May 10, 2017) and the geostrophic velocity anomaly field derived from sea level anomaly data (May 24, 2017) revealed a mesoscale cyclonic eddy in the Florida Straits near the time of egg collection, which likely entrained waters from the West Florida Shelf (WFS) or northwestern coast of Cuba and moved drifting eggs offshore and into the Florida Straits south of the WFS (Figure 2b). 
Discussion

This study presents genetic identification of fish eggs in the waters surrounding Cuba and

211 across the Florida Straits, providing valuable spawning information for many species of

212 commercial, recreational and subsistence importance, including Auxis spp. (tunas), Coryphaena

213 sp. (dolphinfish), Decapterus sp. (scad), Epinephelus adscensionis (Rock Hind), Euthynnus

214 alletteratus (Little Tunny), Istiophorus albicans (Sailfish), Katsuwonus pelamis (Skipjack Tuna),

215 Thunnus spp. (tunas), Lutjanus spp. (snappers), Makaira nigricans (Blue Marlin),

216 Scomberomorus cavalla (King Mackerel), Ocyurus chrysurus (Yellowtail Snapper), Trachinotus

217 falcatus (Permit), and Xiphias gladius (Swordfish). Several of the species that eggs were

218 identified from were also captured as adults in a companion longline survey conducted on the

219 same cruise and stations along the coast of Cuba, including Gymnothorax moringa (Spotted

220 Moray), Thunnus atlanticus (Blackfin Tuna), Ocyurus chrysurus (Yellowtail Snapper), Lutjanus

221 analis (Mutton Snapper), Epinephelus adscensionis (Rock Hind), and Haemulon plumierii

222 (White Grunt) (Murawski et al., 2018).

223 Additionally, this study identified eggs from species not previously known to spawn in

224 this area, including: Luvarus imperialis (Louvar; detected at station F9), Bothus lunatus (Plate

225 Fish; detected at station C6) and Eumegistus illustris (Brilliant Pomfret; detected at stations C4

226 and C6). There is little information on the spawning habits or the duration of larval development

227 in each of these species; therefore, their detection in this region is of significant importance in

228 evaluating regional biodiversity. Only adult specimens of Louvar have been documented in the

229 GoM (Topp \& Girardin, 1971), all from the western coast of Florida. Although gravid females

230 were among the three specimens, our study is the first documented spawning location of the 
231 Louvar in the GoM. L. imperialis larvae have been identified in the northwestern Pacific ocean

232 near Japan (Nishikawa, 1987) and larvae, juveniles, and a single adult specimen with mature

233 gonads were collected in the southwestern Atlantic ocean, near southern Brazil (Domingues et

234 al., 2015). Larval development in this species can take months and larvae can thus travel great

235 distances from spawning locations (Domingues et al., 2015). While little is known about the

236 early life stages of Bothus lunatus (van der Veer et al., 2018), spawning has been observed near

237 Bonaire, Netherlands Antilles (Konstantinou \& Shen, 1995). Juvenile Eumegistus illustris of

238 various sizes have been collected and studied from the Line Islands in Kiribati, and waters near

239 Japan and New Guinea (Moteki \& Mundy, 2005; Okiyawa, 1989).

Determination of the location and timing of spawning for species is valuable for

241 designing conservation strategies, including the creation of Marine Protected Areas (MPAs) and

242 setting fishing strategies to minimize targeting of spawning aggregations. Temporary and

243 permanent MPAs are chosen based on their conservation value and the presence of marine

244 species of ecological and economic importance (Valderrama et al., 2018); protecting spawning

245 sites can be a key component of ensuring sufficient protection of spawning aggregations. For

246 example, one of the species we recovered eggs from, Lutjanus analis (Mutton Snapper),

247 aggregates in May and June in Cuban waters (Claro et al., 2014). Lutjanidae is the most

248 economically important fish family in Cuba, comprising 21\% of total fish catches (Salas et al.,

249 2011). Many of these catches occur during spawning season because spawning aggregations can

250 result in high catch rates as compared to non-spawning periods (Salas et al., 2011). Therefore,

251 closing fishing seasons during times of spawning could decrease mortality of spawning adults

252 and aid in fishery conservation (van Overzee \& Rijnsdorp, 2015). Thus, a strategy for monitoring 
253 fish egg abundance and species composition seasonally and regionally may aid in identifying 254 persistent spawning aggregations.

This study had a higher failure rate (64\%) of DNA barcoding compared to previous 256 studies (Ahern et al., 2018; Burrows et al., 2019; Harada et al., 2015; Lewis et al., 2016; Leyva-

257 Cruz et al., 2016). This low success rate was most likely due to poor preservation technique, 258 since the plankton tow biomass was stored in 30\% isopropanol instead of the intended 70\% 259 isopropanol. The low isopropanol concentration and long-term storage prior to processing is 260 known to negatively affect the long-term stability of DNA (Michaud \& Foran, 2011). This 261 degradation led to the higher failure rate (86\%) in the second batch of samples processed 262 (stations C1-C6, C9, C12 and C13; which were not extracted for over a year) compared to the $26342 \%$ failure rate of the first batch of samples processed (stations F1-F9, C7, C8, C10, C11 and 264 C14; which were extracted within two months of collection). A previous study showed that DNA 265 degradation accelerates after six months of storage in alcohol solutions (Michaud \& Foran, 266 2011). In future studies, proper preservation and rapid processing (no longer than six months 267 after collection) should be considered a high priority. Due to the low success rates of DNA 268 barcoding in the present study, emphasis should be placed on the positive detection of particular 269 taxa, but the lack of detection does not imply absence of spawning of a given taxon.

270 In our previous work in the GoM, there was a clear delineation between neritic (largely 271 reef-associated) fish species spawning on continental shelves, and oceanic species spawning in 272 deeper waters (Burrows et al., 2019). While this observation generally applied in this study as 273 well, eggs from some reef-associated species were found in the deep water of the Florida Straits 274 and eggs from pelagic-associated species were found on or near continental shelves, as seen in 275 Figure 1. For example, fish eggs found at station C3 (165 m) were from pelagic, reef-associated, 
276 demersal, and mixed (taxa either pelagic or reef-associated) species and the eggs found at station

277 C6 (near the shelf break268 m) were mostly pelagic species, possibly due to the steepness of the 278 continental slope off the northwestern coast of Cuba (Claro et al., 2014) and onshore flow from

279 the deep GoM (Figure 2). On the other hand, station C10 (660 m) had eggs from a few reef280 associated species. Many eggs identified at station F7 belonged to reef-associated species but 281 occurred in deeper waters $(667 \mathrm{~m})$ off the Florida coast (Figure 1$)$. This finding is likely due to 282 the presence of a cyclonic eddy off the coast of the Florida Keys at the time of egg collection 283 (Figure 2). Based on the species observed at station F7, which was located toward the distal end 284 of the jet of water, this eddy entrained eggs of Lutjanus sp. (snapper), Diplectrum formosum 285 (Sand Perch), Xyrichtys novacula (Pearly Razorfish), and Haemulon aurolineatum (Tomtate 286 Grunt), all species that are typically found in shallow Cuban waters (Claro et al., 2014) and other 287 shallow GoM waters (Burrows et al., 2019).

The Florida Straits is a relatively narrow channel linking the GoM to the Atlantic Ocean 289 through the Florida Current, which transports a large volume of seawater, 30 Sv per year, at 290 high speeds (Richardson, 2001). In addition to the fast-moving Florida Current, both mesoscale 291 and sub-mesoscale eddies frequently occur in the area (Kourafalou \& Kang, 2012; Lee et al., 292 1995; Shay et al., 1998). Based on long-term satellite ocean color measurements, Zhang et al., 293 (2019) revealed strong seasonality of mesoscale cyclonic eddy occurrence in the Florida Straits 294 with the highest occurrence in the summer and lowest occurrence in the winter. These cyclonic 295 eddies are highly productive ecosystems that are rich in nutrients, phytoplankton, and copepods 296 (Hitchcock et al., 2005; Lee et al., 1994) and can influence cross-shelf transport of fish larvae 297 (Lane et al., 2003; Lee et al., 1992; Limouzy-Paris et al., 1997; Shulzitski et al., 2017; Shulzitski 298 et al., 2016; Sponaugle et al., 2005). Sponaugle et al. (2005) showed that larvae can be 
concentrated by mesoscale eddies and transported from the lower to upper Florida Keys. Our

findings extend this observation by providing evidence of entrainment of eggs spawned by reef fishes on the WFS into the deep Florida Straits via a mesoscale eddy. Calculations based on an average egg longevity of 24 hours (Pauly \& Pullin, 1988) and assuming an average speed of $1 \mathrm{~m}$ $\mathrm{s}^{-1}$ for the Florida Current (Kourafalou \& Kang, 2012) estimate that fish eggs could travel $86 \mathrm{~km}$ prior to hatching into larvae. Therefore, it is feasible that the fish eggs identified at station F7 could have been transported from the WFS (about $81 \mathrm{~km}$ away following the inner circle of the eddy seen in Figure 2) by the mesoscale eddy observed in this region. In a second scenario, fish eggs could have been transported via the same eddy seen in Figure 2 from the northwestern Cuba coast (about $140 \mathrm{~km}$ away from station F7) if the eggs did not hatch for about 39 hours. Based on altimetry measurements, the cyclonic eddy observed in this study was present for about 3 months (from April 18, 2017 through July 19, 2017). The formation and disappearance of this eddy can be seen in the Supplementary Animation. In these scenarios, after the fish eggs hatch to larvae, they could be transported back to the continental shelf of southern Florida (Florida Keys) or be swept up closer to the eastern coast of Florida.

\section{Conclusion}

This study provided novel information about reproduction of commercially and ecologically important species along the southwestern Florida coast, northwestern Cuban coast, and in the Florida Straits. For most stations, eggs from reef-associated species were found in relatively shallow waters close to continental shelves, while eggs from pelagic species were found in relatively deep waters off continental shelves. However, the mesoscale eddy observed in the Florida Straits suggested that oceanographic processes were able to transport reef- 
associated fish eggs away from spawning locations and into deeper waters, revealing a possible explanation for the detection of reef-associated species in deep waters. Such information can allow fisheries scientists to combine knowledge of biological and physical processes to better estimate the spawning locations and fate of fish early life stages. This pilot study demonstrates the power of these techniques for identifying critical habitats to conserve species of interest and defining the timing, locations and interrelationships of fish spawning in the waters surrounding Florida and Cuba.

\section{Footnote}

1 - The intended method of preservation was 70\% isopropanol, but there was a miscommunication in the protocol.

\section{viii. REFERENCES}

Ahern, A. L. M., Gómez-Gutiérrez, J., Aburto-Oropeza, O., Saldierna-Martínez, R. J., Johnson, A. F., Harada, A. E., . . . Burton, R. S. (2018). DNA sequencing of fish eggs and larvae reveals high species diversity and seasonal changes in spawning activity in the southeastern Gulf of California. Marine Ecology Progress Series, 592, 159-179. doi:10.3354/meps12446

Burghart, S. E., Van Woudenberg, L., Daniels, C. A., Meyers, S. D., Peebles, E. B., \& Breitbart, M. (2014). Disparity between planktonic fish egg and larval communities as indicated by DNA barcoding. Marine Ecology Progress Series, 503, 195-204. doi:10.3354/meps10752

Burrows, M., Browning, J. S., Breitbart, M., Murawski, S. A., \& Peebles, E. B. (2019). DNA barcoding reveals clear delineation between spawning sites for neritic versus oceanic fishes in the Gulf of Mexico. Fisheries Oceanography, 28(2), 228-239. doi:10.1111/fog.12404

Chow, S., \& Inoue, S. (1993). Intra-and interspecific restriction fragment length polymorphism in mitochondrial genes of Thunnus tuna species. Bulletin of National Research Institute Far Seas Fisheries, 30, 207-225. 
Claro, R., Lindeman, K. C., \& Parenti, L. R. (2014). Ecology of the marine fishes of Cuba: Smithsonian Institution.

Cowen, R. K., \& Sponaugle, S. (2009). Larval dispersal and marine population connectivity. Annual Review of Marine Science, 1, 443-466. doi:10.1146/annurev.marine.010908.163757

Domingues, R., Montealegre-Quijano, S., Soto, J., \& Amorim, A. (2015). Five new records of Luvarus imperialis (Acanthuroidei: Luvaridae) in the south-west Atlantic Ocean. Journal of Fish Biology, 86(3), 1203-1208. doi:10.1111/jfb.12629

Duke, E. M., Harada, A. E., \& Burton, R. S. (2018). Large interannual variation in spawning in San Diego marine protected areas captured by molecular identification of fish eggs. Marine Ecology Progress Series, 604, 199-210. doi:10.3354/meps12738

Fabra, M., Raldúa, D., Power, D. M., Deen, P. M., \& Cerda, J. (2005). Marine fish egg hydration is aquaporin-mediated. Science, 307(5709), 545-545. doi:10.1126/science.1106305

Froese, R. a. D. P. (2019, 08/2019). FishBase.

Harada, A. E., Lindgren, E. A., Hermsmeier, M. C., Rogowski, P. A., Terrill, E., \& Burton, R. S. (2015). Monitoring spawning activity in a southern California Marine Protected Area using molecular identification of fish eggs. PLOS ONE, 10(8), e0134647. doi:10.1371/journal.pone.0134647

Hitchcock, G. L., Lee, T. N., Ortner, P. B., Cummings, S., Kelble, C., \& Williams, E. (2005). Property fields in a Tortugas Eddy in the southern Straits of Florida. Deep Sea Research Part I: Oceanographic Research Papers, 52(12), 2195-2213. doi:10.1016/j.dsr.2005.08.006

Ionin, A., Pavlidis, Y., \& Avello, O. (1977). Geología de la plataforma marina de Cuba. Editorial Nauka, Moscú, 364.

Ivanova, N. V., Zemlak, T. S., Hanner, R. H., \& Hebert, P. D. (2007). Universal primer cocktails for fish DNA barcoding. Molecular Ecology Resources, 7(4), 544-548. doi:10.1111/j.1471-8286.2007.01748.x

Kawakami, T., Aoyama, J., \& Tsukamoto, K. (2010). Morphology of pelagic fish eggs identified using mitochondrial DNA and their distribution in waters West of the Mariana Islands. Environmental Biology of Fishes, 87(3), 221-235. doi:10.1007/s10641-010-9592-2

Konstantinou, H., \& Shen, D. C. (1995). The social and reproductive behavior of the eyed flounder, Bothus ocellatus, with notes on the spawning of Bothus lunatus and Bothus ellipticus. Environmental Biology of Fishes, 44(4), 311-324. doi:10.1007/BF00008245

Kourafalou, V. H., \& Kang, H. (2012). Florida Current meandering and evolution of cyclonic eddies along the Florida Keys Reef Tract: Are they interconnected? Journal of Geophysical Research: Oceans, 117(C5). doi:10.1029/2011JC007383 
Lane, P. V., Smith, S. L., Graber, H. C., \& Hitchcock, G. L. (2003). Mesoscale circulation and the surface distribution of copepods near the south Florida Keys. Bulletin of Marine Science, 72(1), 1-18.

Larson, J. H., Grace McCalla, S., Chapman, D. C., Rees, C., Knights, B. C., Vallazza, J. M., . . . Amberg, J. (2016). Genetic analysis shows that morphology alone cannot distinguish Asian Carp eggs from those of other cyprinid species. North American Journal of Fisheries Management, 36(5), 1053-1058. doi:10.1080/02755947.2016.1185057

Lee, T. N., Clarke, M., Williams, E., Szmant, A. F., \& Berger, T. (1994). Evolution of the Tortugas Gyre and its influence on recruitment in the Florida Keys. Bulletin of Marine Science, 54(3), 621-646.

Lee, T. N., Leaman, K., Williams, E., Berger, T., \& Atkinson, L. (1995). Florida Current meanders and gyre formation in the southern Straits of Florida. Journal of Geophysical Research: Oceans, 100(C5), 8607-8620. doi:10.1029/94JC02795

Lee, T. N., Rooth, C., Williams, E., McGowan, M., Szmant, A. F., \& Clarke, M. (1992). Influence of Florida Current, gyres and wind-driven circulation on transport of larvae and recruitment in the Florida Keys coral reefs. Continental Shelf Research, 12(7-8), 9711002. doi:10.1016/0278-4343(92)90055-O

Lewis, L. A., Richardson, D. E., Zakharov, E. V., \& Hanner, R. (2016). Integrating DNA barcoding of fish eggs into ichthyoplankton monitoring programs. Fishery Bulletin, 114(2), 153-165.

Leyva-Cruz, E., Vásquez-Yeomans, L., Carrillo, L., \& Valdez-Moreno, M. (2016). Identifying pelagic fish eggs in the southeast Yucatan Peninsula using DNA barcodes. Genome, 59(12), 1117-1129. doi:10.1139/gen-2015-0151

Limouzy-Paris, C., Graber, H. C., Jones, D. L., Röpke, A. W., \& Richards, W. J. (1997). Translocation of larval coral reef fishes via sub-mesoscale spin-off eddies from the Florida Current. Bulletin of Marine Science, 60(3), 966-983.

Limouzy-Paris, C., McGowan, M., Richards, W., Umaran, J., \& Cha, S. (1994). Diversity of fish larvae in the Florida Keys: results from SEFCAR. Bulletin of Marine Science, 54(3), 857870.

Michaud, C. L., \& Foran, D. R. (2011). Simplified field preservation of tissues for subsequent DNA analyses. Journal of forensic sciences, 56(4), 846-852. doi:10.1111/j.15564029.2011.01771.x

Moteki, M., \& Mundy, B. C. (2005). Notes on the morphology of the early stage of the rare bramid genus Eumegistus. Ichthyological Research, 52(4), 401-405. doi:10.1007/s10228005-0294-2

Murawski, S. A., Peebles, E. B., Gracia, A., Tunnell Jr, J. W., \& Armenteros, M. (2018). Comparative abundance, species composition, and demographics of continental shelf fish 
assemblages throughout the Gulf of Mexico. Marine and Coastal Fisheries, 10(3), 325346. doi:10.1002/mcf2.10033

Nishikawa, Y. (1987). Larval morphology and occurrence of the Louvar, Luvarus imperialis (Luvaridae). Japanese Journal of Ichthyology, 34(2), 215-221. doi:10.1007/bf02912417

Okiyawa, M. (1989). An atlas of the early stage fishes in Japan. In. Retrieved from https://escholarship.org/uc/item/9284j82s

Paine, M. A., McDowell, J. R., \& Graves, J. E. (2007). Specific identification of western Atlantic Ocean Scombrids using mitochondrial DNA cytochrome c oxidase subunit I (COI) gene region sequences. Bulletin of Marine Science, 80(2), 353-367.

Pauly, D., \& Pullin, R. S. (1988). Hatching time in spherical, pelagic, marine fish eggs in response to temperature and egg size. Environmental Biology of Fishes, 22(4), 261-271. doi:10.1007/BF00004892

Peebles, E., \& Tolley, S. (1988). Distribution, growth and mortality of larval Spotted Seatrout, Cynoscion nebulosus: a comparison between two adjacent estuarine areas of southwest Florida. Bulletin of Marine Science, 42(3), 397-410.

Richardson. (2001). Florida Current, Gulf Stream, and Labrador Current. In Encyclopedia of Ocean Sciences (Vol. 2, pp. 1054-1064): Elsevier Ltd.

Richardson, D. E., Llopiz, J. K., Leaman, K. D., Vertes, P. S., Muller-Karger, F. E., \& Cowen, R. K. (2009). Sailfish (Istiophorus platypterus) spawning and larval environment in a Florida Current frontal eddy. Progress in Oceanography, 82(4), 252-264. doi:10.1016/j.pocean.2009.07.003

Salas, S., Chuenpagdee, R., Charles, A. T., \& Seijo, J. C. (2011). Coastal fisheries of Latin America and the Caribbean (Vol. 544): Food and Agriculture Organization of the United Nations Rome.

Sassa, C., Konishi, Y., \& Mori, K. (2006). Distribution of Jack Mackerel (Trachurus japonicus) larvae and juveniles in the East China Sea, with special reference to the larval transport by the Kuroshio Current. Fisheries Oceanography, 15(6), 508-518. doi:10.1111/j.13652419.2006.00417.x

Shay, L. K., Lee, T. N., Williams, E. J., Graber, H. C., \& Rooth, C. G. (1998). Effects of lowfrequency current variability on near-inertial submesoscale vortices. Journal of Geophysical Research: Oceans, 103(C9), 18691-18714. doi:10.1029/98JC01007

Shulzitski, K., Sponaugle, S., Hauff, M., Walter, K., D’Alessandro, E., \& Cowen, R. (2017). Patterns in larval reef fish distributions and assemblages, with implications for local retention in mesoscale eddies. Canadian Journal of Fisheries and Aquatic Sciences, 75(2), 180-192. doi:10.1139/cjfas-2016-0304 
Shulzitski, K., Sponaugle, S., Hauff, M., Walter, K. D., \& Cowen, R. K. (2016). Encounter with mesoscale eddies enhances survival to settlement in larval coral reef fishes. Proceedings of the National Academy of Sciences, 113(25), 6928-6933. doi:10.1073/pnas.1601606113

Smith, P., McVeagh, S. M., Allain, V., \& Sanchez, C. (2005). DNA identification of gut contents of large pelagic fishes. Journal of Fish Biology, 67(4), 1178-1183. doi:10.1111/j.00221112.2005.00804.x

Sponaugle, S., Lee, T., Kourafalou, V., \& Pinkard, D. (2005). Florida Current frontal eddies and the settlement of coral reef fishes. Limnology and Oceanography, 50(4), 1033-1048. doi:10.4319/lo.2005.50.4.1033

Thresher, R. E. (1984). Reproduction in reef fishes. Neptune City, NJ: T.F.H. Publications, Inc.

Topp, R. W., \& Girardin, D. L. (1971). An adult louvar, Luvarus imperialis (Pisces, Luvaridae), from the Gulf of Mexico. Copeia, 1971(1), 181-182.

Truett, G., Heeger, P., Mynatt, R., Truett, A., Walker, J., \& Warman, M. (2000). Preparation of PCR-quality mouse genomic DNA with hot Sodium Hydroxide and Tris (HotSHOT). Biotechniques, 29(1), 52, 54. doi:10.2144/00291bm09

Valderrama, S. P., Ávila, A. H., Méndez, J. G., Martínez, O. M., Rojas, D. C., Ferro Azcona, H., ... Pina-Amargós, F. (2018). Marine protected areas in Cuba. Bulletin of Marine Science, 94(2), 423-442. doi:10.5343/bms.2016.1129

van der Veer, H. W., Cardoso, J. F., Mateo, I., Witte, J. I., \& van Duyl, F. C. (2018). Occurrence and life history characteristics of tropical flatfishes at the coral reefs of Curaçao, Dutch Caribbean. Journal of Sea Research, 142, 157-166. doi:10.1016/j.seares.2018.09.010

van Overzee, H. M., \& Rijnsdorp, A. D. (2015). Effects of fishing during the spawning period: implications for sustainable management. Reviews in Fish Biology and Fisheries, 25(1), 65-83. doi:10.1007/s11160-014-9370-х

Vikebø, F., Jørgensen, C., Kristiansen, T., \& Fiksen, Ø. (2007). Drift, growth, and survival of larval Northeast Arctic cod with simple rules of behaviour. Marine Ecology Progress Series, 347, 207-219. doi:10.3354/meps06979

Ward, R. D., Hanner, R., \& Hebert, P. D. (2009). The campaign to DNA barcode all fishes, FISH-BOL. Journal of Fish Biology, 74(2), 329-356. doi:10.1111/j.10958649.2008.02080.x

Zhang, Y., Hu, C., Liu, Y., Weisberg, R. H., \& Kourafalou, V. H. (2019). Submesoscale and mesoscale eddies in the Florida Straits: Observations from satellite ocean color measurements. Geophysical Research Letters, 46(22), 13262-13270. doi:10.1029/2019GL083999 
497 Table 1: Cruise information (sampling date, depth, latitude, and longitude) of the 23 sampled 498 stations and the total egg density at each station. The total egg density in sample C8 could not be 499 calculated because there was excessive Sargassum in the sample. C = Cuba, F = Florida Straits.

\begin{tabular}{|c|c|c|c|c|c|}
\hline Station & $\begin{array}{r}\text { Date } \\
\text { (YYMMDD) }\end{array}$ & Depth (m) & Latitude & Longitude & $\begin{array}{r}\text { Total egg density } \\
\left(\text { eggs } / \mathrm{m}^{3}\right)\end{array}$ \\
\hline C1 & 170513 & 223 & $23.19^{\circ} \mathrm{N}$ & $82.08^{\circ} \mathrm{W}$ & 7.36 \\
\hline $\mathrm{C} 2$ & 170513 & 292 & $23.19^{\circ} \mathrm{N}$ & $82.11^{\circ} \mathrm{W}$ & 4.52 \\
\hline C3 & 170514 & 165 & $23.03^{\circ} \mathrm{N}$ & $82.76^{\circ} \mathrm{W}$ & 0.62 \\
\hline C4 & 170514 & 464 & $23.04^{\circ} \mathrm{N}$ & $82.75^{\circ} \mathrm{W}$ & 0.23 \\
\hline C5 & 170515 & 416 & $23.02^{\circ} \mathrm{N}$ & $83.02^{\circ} \mathrm{W}$ & 3.38 \\
\hline C6 & 170515 & 268 & $23.03^{\circ} \mathrm{N}$ & $82.97^{\circ} \mathrm{W}$ & 0.33 \\
\hline C7 & 170518 & 782 & $22.16^{\circ} \mathrm{N}$ & $84.81^{\circ} \mathrm{W}$ & 0.02 \\
\hline $\mathrm{C8}$ & 170518 & 252 & $22.10^{\circ} \mathrm{N}$ & $84.85^{\circ} \mathrm{W}$ & Not calculated* \\
\hline C9 & 170519 & 255 & $22.45^{\circ} \mathrm{N}$ & $84.53^{\circ} \mathrm{W}$ & 0.07 \\
\hline C10 & 170519 & 660 & $22.49^{\circ} \mathrm{N}$ & $84.53^{\circ} \mathrm{W}$ & 0.12 \\
\hline C11 & 170521 & 501 & $22.73^{\circ} \mathrm{N}$ & $84.07^{\circ} \mathrm{W}$ & 9.44 \\
\hline C12 & 170521 & 122 & $22.71^{\circ} \mathrm{N}$ & $84.09^{\circ} \mathrm{W}$ & 2.22 \\
\hline C13 & 170522 & 286 & $22.91^{\circ} \mathrm{N}$ & $83.56^{\circ} \mathrm{W}$ & 6.76 \\
\hline C14 & 170523 & 350 & $23.00^{\circ} \mathrm{N}$ & $83.16^{\circ} \mathrm{W}$ & 3.51 \\
\hline F1 & 170524 & 1665 & $23.17^{\circ} \mathrm{N}$ & $82.77^{\circ} \mathrm{W}$ & 0.18 \\
\hline F2 & 170524 & 1996 & $23.34^{\circ} \mathrm{N}$ & $82.77^{\circ} \mathrm{W}$ & 0.34 \\
\hline F3 & 170524 & 1764 & $23.50^{\circ} \mathrm{N}$ & $82.77^{\circ} \mathrm{W}$ & 0.22 \\
\hline F4 & 170524 & 1594 & $23.67^{\circ} \mathrm{N}$ & $82.77^{\circ} \mathrm{W}$ & 0.07 \\
\hline F5 & 170524 & 1774 & $23.83^{\circ} \mathrm{N}$ & $82.77^{\circ} \mathrm{W}$ & 0.02 \\
\hline F6 & 170524 & 865 & $23.99^{\circ} \mathrm{N}$ & $82.77^{\circ} \mathrm{W}$ & 0.09 \\
\hline F7 & 170525 & 667 & $24.17^{\circ} \mathrm{N}$ & $82.76^{\circ} \mathrm{W}$ & 0.06 \\
\hline F8 & 170525 & 113 & $24.35^{\circ} \mathrm{N}$ & $82.75^{\circ} \mathrm{W}$ & 4.70 \\
\hline F9 & 170525 & 19 & $24.50^{\circ} \mathrm{N}$ & $82.76^{\circ} \mathrm{W}$ & 1.90 \\
\hline
\end{tabular}

500

$501 \quad$ x. Figure legends 
502 Figure 1: Map of bongo net deployment stations with number of fish eggs by habitat type from 503 May 2017. F= Florida Straits, C=Cuba. Raw data are available in Table 1 and Supplemental

504 Table 1. Mixed stations are those with taxa not identified down to species level, so their habitats 505 are either pelagic, reef-associated, or demersal. The total number of eggs per station represents 506 the amount of eggs successfully barcoded. Map made in ArcGIS.

Figure 2: Mesoscale cyclonic eddy in the Florida Straits. a: A snapshot of MODIS/Aqua chlorophyll $a$ concentration on May 10, 2017 (white color means no data). b: The geostrophic velocity anomaly field derived from sea level anomaly data on May 24, 2017. Fish egg collection

511 stations are marked with black stars. Note that Figure 2b represents the time of collection (see 512 Table 1) better than Figure 2a.

Supplementary Animation: The formation and disappearance of the Florida Straits mesoscale cyclonic eddy. This animation shows the geostrophic velocity anomaly field derived from sea level anomaly data from April 10, 2017 through July 25, 2017.

\section{Conflict of Interest:} interest in the subject matter discussed in this manuscript.

\section{Ethics Statement:}

523 Consent was received for all research conducted in this manuscript, with all participants

524 voluntarily involved. We ensure quality and integrity of the research involved and we are

525 independent and impartial to the results.

527 Author Contribution Statement:

528 All authors discussed the results and contributed to the final manuscript. 


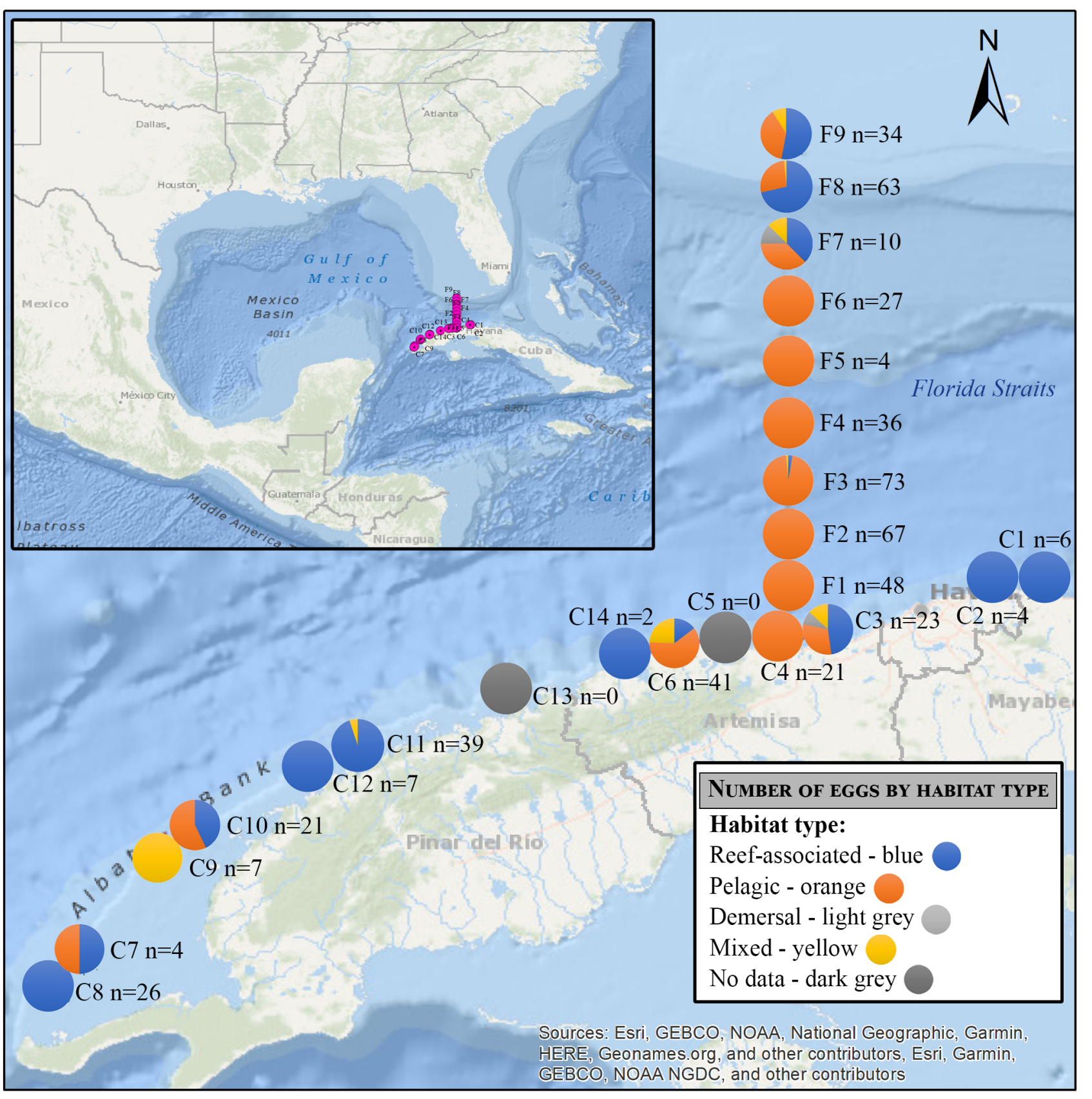




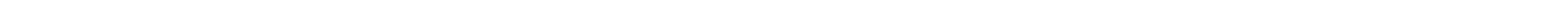


Supplemental Table 1: Fish egg species identification (common name, habitat, and economic importance information from www.fishbase.org). Multiple species on one row indicates genetic analysis could not discriminate between species in the database.

\begin{tabular}{|c|c|c|c|c|c|}
\hline Taxon & Common Name & Habitat & Economic Importance & $\begin{array}{c}\text { Encounter } \\
\text { Frequency } \\
\text { (Stations) } \\
\end{array}$ & $\begin{array}{l}\text { Station(s) Eggs } \\
\text { Encountered }\end{array}$ \\
\hline $\begin{array}{l}\text { Acanthurus bahianus/ } \\
\text { A. tractus }\end{array}$ & $\begin{array}{l}\text { Barber Surgeonfish/Ocean } \\
\text { Surgeonfish }\end{array}$ & reef-associated & $\begin{array}{l}\text { no/aquarium; minor } \\
\text { commercial }\end{array}$ & 1 & C8 \\
\hline Acanthurus chirurgus & Doctorfish & reef-associated & $\begin{array}{l}\text { aquarium; minor } \\
\text { commercial }\end{array}$ & 5 & $\begin{array}{l}\text { C6, C3, C2, C1, } \\
\text { C12 }\end{array}$ \\
\hline Acanthurus coeruleus & Blue Tang Surgeonfish & reef-associated & $\begin{array}{l}\text { aquarium; minor } \\
\text { commercial }\end{array}$ & 3 & C3, C8, C11 \\
\hline Auxis thazard & Frigate Tuna & pelagic-neritic & commercial; gamefish & 1 & F8 \\
\hline Auxis thazard/A. rochei & Frigate/Bullet Tuna & pelagic-neritic & commercial; gamefish & 1 & F8 \\
\hline Bothus lunatus & Plate fish & reef-associated & minor commercial & 1 & C6 \\
\hline Brama dussumieri & Lesser Bream & pelagic-neritic & commercial & 1 & F5 \\
\hline $\begin{array}{l}\text { Brama orcini/ } \\
\text { B. cf. dussumieri }\end{array}$ & $\begin{array}{l}\text { Bigtooth Pomfret/ Lesser } \\
\text { Bream }\end{array}$ & $\begin{array}{l}\text { benthopelagic/ } \\
\text { pelagic-neritic }\end{array}$ & $\begin{array}{l}\text { minor commercial/ } \\
\text { commercial }\end{array}$ & 1 & F5 \\
\hline Caranginae sp. & Scad & reef-associated & $\begin{array}{l}\text { minor commercial; } \\
\text { gamefish }\end{array}$ & 1 & F8 \\
\hline Chaetodon sedentarius & Reef Butterflyfish & reef-associated & aquarium & 1 & C12 \\
\hline Chaetodon striatus & Banded Butterflyfish & reef-associated & aquarium & 1 & C8 \\
\hline Coryphaena hippurus & Common Dolphinfish & pelagic-neritic & commercial; gamefish & 1 & F4 \\
\hline $\begin{array}{l}\text { Coryphaena hippurus/ } \\
\text { C. equiselis }\end{array}$ & Common/Pompano Dolphinfish & pelagic-neritic & commercial; gamefish & 3 & F1, F4, F6 \\
\hline $\begin{array}{l}\text { Decapterus macarellus/ } \\
\text { D. tabl }\end{array}$ & $\begin{array}{l}\text { Mackerel/ } \\
\text { Roughear Scad }\end{array}$ & $\begin{array}{l}\text { pelagic-oceanic/ } \\
\text { reef associated }\end{array}$ & $\begin{array}{l}\text { commercial; } \\
\text { gamefish/minor } \\
\text { commercial }\end{array}$ & 3 & C3, C9, C6 \\
\hline $\begin{array}{l}\text { Decapterus punctatus/ } \\
\text { D. tabl }\end{array}$ & $\begin{array}{l}\text { Round/ } \\
\text { Roughear Scad }\end{array}$ & reef-associated & minor commercial & 3 & F3, F8, C8 \\
\hline Diodon holocanthus & Longspined Porcupinefish & reef-associated & $\begin{array}{l}\text { aquarium; minor } \\
\text { commercial }\end{array}$ & 1 & C8 \\
\hline Diplectrum formosum & Sand Perch & reef-associated & commercial; gamefish & 1 & F7 \\
\hline Diplospinus multistriatus & Striped Escolar & benthopelagic & subsistence fisheries & 2 & F9, C4 \\
\hline $\begin{array}{l}\text { Diplospinus multistriatus/Nealotus } \\
\text { tripes }\end{array}$ & $\begin{array}{l}\text { Striped Escolar/Black Snake } \\
\text { Mackerel }\end{array}$ & $\begin{array}{l}\text { benthopelagic/ } \\
\text { bathypelagic }\end{array}$ & subsistence fisheries & 4 & F3, F4, F6, F7 \\
\hline Epinephelus adscensionis & Rock Hind & demersal & commercial; gamefish & 1 & C3 \\
\hline
\end{tabular}




\begin{tabular}{|c|c|c|c|c|c|}
\hline Taxon & FishBase Common Name & Habitat & Economic Importance & $\begin{array}{l}\text { Encounter } \\
\text { Frequency } \\
\text { (Stations) }\end{array}$ & $\begin{array}{l}\text { Station(s) Eggs } \\
\text { Encountered }\end{array}$ \\
\hline Eucinostomus argenteus & Silver Mojarra & reef-associated & minor commercial & 1 & C11 \\
\hline $\begin{array}{l}\text { Eucinostomus argenteus/E. } \\
\text { harengulus }\end{array}$ & Silver/Tidewater Mojarra & $\begin{array}{l}\text { reef- } \\
\text { associated/demers } \\
\text { al }\end{array}$ & minor commercial/no & 2 & F9, C11 \\
\hline $\begin{array}{l}\text { Eucinostomus argenteus/ } \\
\text { E. harengulus/E. gula }\end{array}$ & $\begin{array}{l}\text { Silver/Tidewater/ } \\
\text { Jenny Mojarra }\end{array}$ & $\begin{array}{l}\text { reef-associated/ } \\
\text { demersal/ } \\
\text { reef-associated }\end{array}$ & $\begin{array}{l}\text { minor commercial/no/ } \\
\text { minor commercial }\end{array}$ & 1 & C11 \\
\hline $\begin{array}{l}\text { Eucinostomus argenteus/ } \\
\text { E. harengulus/E. lefroyi }\end{array}$ & $\begin{array}{l}\text { Silver/Tidewater/ } \\
\text { Mottled Mojarra }\end{array}$ & $\begin{array}{l}\text { reef-associated/ } \\
\text { demersal/ } \\
\text { reef-associated }\end{array}$ & $\begin{array}{l}\text { minor commercial/ no/ } \\
\text { minor commercial }\end{array}$ & 2 & F3, F9 \\
\hline Eumegistus illustris & Brilliant Pomfret & bathypelagic & no & 2 & C6, C4 \\
\hline Euthynnus alletteratus & Little Tunny & reef-associated & commercial; gamefish & 1 & F8 \\
\hline $\begin{array}{l}\text { Euthynnus alletteratus/ } \\
\text { Auxis thazard }\end{array}$ & $\begin{array}{l}\text { Little Tunny/ } \\
\text { Frigate Tuna } \\
\end{array}$ & $\begin{array}{l}\text { reef-associated/ } \\
\text { pelagic-neritic }\end{array}$ & commercial; gamefish & 1 & F8 \\
\hline Gymnothorax moringa & Spotted Moray & reef-associated & $\begin{array}{l}\text { aquarium; minor } \\
\text { commercial }\end{array}$ & 1 & C10 \\
\hline Haemulon aurolineatum & Tomtate Grunt & reef-associated & $\begin{array}{l}\text { aquarium; minor } \\
\text { commercial }\end{array}$ & 3 & C11, F3, F7 \\
\hline Haemulon carbonarium & Caesar Grunt & reef-associated & $\begin{array}{l}\text { aquarium; minor } \\
\text { commercial }\end{array}$ & 1 & $\mathrm{C} 3$ \\
\hline Haemulon flavolineatum & French Grunt & reef-associated & aquarium; commercial & 2 & C11, C8 \\
\hline $\begin{array}{l}\text { Haemulon flavolineatum/ } \\
\text { H. aurolineatum }\end{array}$ & $\begin{array}{l}\text { French/ } \\
\text { Tomtate Grunt }\end{array}$ & reef-associated & $\begin{array}{l}\text { aquarium; commercial/ } \\
\text { minor commercial }\end{array}$ & 2 & C11, C3 \\
\hline Haemulon plumierii & White Grunt & reef-associated & $\begin{array}{l}\text { aquarium; minor } \\
\text { commercial; gamefish }\end{array}$ & 1 & C11 \\
\hline Halichoeres bivittatus & Slippery Dick & reef-associated & aquarium & 3 & C11, C6, C8 \\
\hline Halichoeres dimidiatus & Yellowcheek Wrasse & reef-associated & no & 1 & C6 \\
\hline Halichoeres garnoti & Yellowhead Wrasse & reef-associated & aquarium & 1 & $\mathrm{C} 8$ \\
\hline Halichoeres radiatus & Puddingwife Wrasse & reef-associated & $\begin{array}{l}\text { aquarium; minor } \\
\text { commercial }\end{array}$ & 3 & C11, C6, C1 \\
\hline $\begin{array}{l}\text { Holacanthus ciliaris/ } \\
\text { H. bermudensis }\end{array}$ & Queen/Bermuda Blue Angelfish & reef-associated & $\begin{array}{l}\text { aquarium; minor } \\
\text { commercial }\end{array}$ & 1 & $\mathrm{C} 8$ \\
\hline Istiophorus albicans & Sailfish & pelagic-oceanic & commercial; gamefish & 1 & F9 \\
\hline
\end{tabular}




\begin{tabular}{|c|c|c|c|c|c|}
\hline Taxon & FishBase Common Name & Habitat & Economic Importance & $\begin{array}{l}\text { Encounter } \\
\text { Frequency } \\
\text { (Stations) }\end{array}$ & $\begin{array}{l}\text { Station(s) Eggs } \\
\text { Encountered }\end{array}$ \\
\hline Kajikia albida & White Marlin & pelagic-oceanic & $\begin{array}{l}\text { minor commercial; } \\
\text { gamefish }\end{array}$ & 1 & $\mathrm{C} 3$ \\
\hline Katsuwonus pelamis & Skipjack Tuna & pelagic-oceanic & commercial; gamefish & 5 & F1, F2, F3, F9, C10 \\
\hline $\begin{array}{l}\text { Katsuwonus pelamis/ } \\
\text { Thunnus atlanticus/ } \\
\text { T. thynnus }\end{array}$ & Skipjack/Blackfin/ Bluefin Tuna & pelagic-oceanic & commercial; gamefish & 1 & $\mathrm{C} 4$ \\
\hline Kyphosus incisor & Yellow Sea Chub & reef-associated & $\begin{array}{l}\text { gamefish/minor } \\
\text { commercial; gamefish }\end{array}$ & 1 & C8 \\
\hline Lactophrys bicaudalis & Spotted Trunkfish & reef-associated & aquarium & 1 & $\mathrm{C} 7$ \\
\hline Lactophrys trigonus & Buffalo Trunkfish & reef-associated & aquarium; commercial & 2 & C10, C11 \\
\hline Lactophrys triqueter & Smooth Trunkfish & reef-associated & $\begin{array}{l}\text { aquarium; minor } \\
\text { commercial }\end{array}$ & 1 & C10 \\
\hline Lampris guttatus & Opah & bathypelagic & $\begin{array}{l}\text { minor commercial; } \\
\text { gamefish }\end{array}$ & 1 & F4 \\
\hline Lutjanus analis & Mutton Snapper & reef-associated & commercial; gamefish & 1 & C8 \\
\hline $\begin{array}{l}\text { Lutjanus analis/ } \\
\text { L. purpureus }\end{array}$ & $\begin{array}{l}\text { Mutton/ } \\
\text { Southern Red Snapper }\end{array}$ & $\begin{array}{l}\text { reef-associated/ } \\
\text { demersal }\end{array}$ & $\begin{array}{l}\text { commercial; gamefish/ } \\
\text { commercial }\end{array}$ & 2 & F7, C6 \\
\hline Lutjanus apodus & Schoolmaster Snapper & reef-associated & commercial & 4 & C8, C10, C11, C3 \\
\hline Lutjanus griseus & Mangrove Snapper & reef-associated & commercial; gamefish & 2 & C8, C11 \\
\hline $\begin{array}{l}\text { Lutjanus mahogoni/ } \\
\text { L. synagris }\end{array}$ & $\begin{array}{l}\text { Mahogany/ } \\
\text { Lane Snapper }\end{array}$ & reef-associated & commercial; gamefish & 1 & C12 \\
\hline Lutjanus synagris & Lane Snapper & reef-associated & commercial; gamefish & 2 & F9, C11 \\
\hline Luvarus imperialis & Louvar & pelagic-oceanic & minor commercial & 1 & F9 \\
\hline Makaira nigricans & Blue Marlin & pelagic-oceanic & commercial; gamefish & 1 & C6 \\
\hline Istiophoridae sp. & Marlin & pelagic-oceanic & gamefish & 1 & C6 \\
\hline Malacanthus plumieri & Sand Tilefish & reef-associated & minor commercial & 1 & $\mathrm{C} 8$ \\
\hline Neoepinnula americana & American Sackfish & benthopelagic & no & 1 & $\mathrm{C} 3$ \\
\hline Nesiarchus nasutus & Black Gemfish & benthopelagic & minor commercial & 1 & F3 \\
\hline Ocyurus chrysurus & Yellowtail Snapper & reef-associated & $\begin{array}{l}\text { aquarium; commercial; } \\
\text { gamefish }\end{array}$ & 4 & F9, C8, C11, C12 \\
\hline Peristedion truncatum & Black Armoured Searobin & bathydemersal & no & 1 & F7 \\
\hline
\end{tabular}




\begin{tabular}{|c|c|c|c|c|c|}
\hline Taxon & FishBase Common Name & Habitat & Economic Importance & $\begin{array}{c}\text { Encounter } \\
\text { Frequency } \\
\text { (Stations) } \\
\end{array}$ & $\begin{array}{l}\text { Station(s) Eggs } \\
\text { Encountered }\end{array}$ \\
\hline Pomacanthus arcuatus & Gray Angelfish & reef-associated & $\begin{array}{l}\text { aquarium; minor } \\
\text { commercial }\end{array}$ & 1 & C8 \\
\hline $\begin{array}{l}\text { Pomacanthus arcuatus/ } \\
\text { P. paru }\end{array}$ & $\begin{array}{l}\text { Gray/ } \\
\text { French Angelfish }\end{array}$ & reef-associated & $\begin{array}{l}\text { aquarium; minor } \\
\text { commercial }\end{array}$ & 1 & C8 \\
\hline Prognichthys occidentalis & Western Bluntnose Flyingfish & pelagic-neritic & no & 4 & C7, F4, F6, F7 \\
\hline Psenes maculatus/Cubiceps baxteri & $\begin{array}{l}\text { Silver Driftfish/ } \\
\text { Black Flathead }\end{array}$ & pelagic-oceanic & no & 3 & F4, F5, F6 \\
\hline Psenes cyanophrys/P. pellucidus & $\begin{array}{l}\text { Freckled/ } \\
\text { Bluefin Driftfish }\end{array}$ & bathypelagic & no/commercial & 1 & F4 \\
\hline $\begin{array}{l}\text { Psenes pellucidus/ P. maculatus/ } \\
\text { Centrolophus niger }\end{array}$ & $\begin{array}{l}\text { Bluefin/Silver/ } \\
\text { Rudderfish }\end{array}$ & $\begin{array}{l}\text { bathypelagic/ } \\
\text { benthopelagic }\end{array}$ & $\begin{array}{l}\text { commercial/no } \\
\text { gamefish }\end{array}$ & 1 & $\mathrm{~F} 4$ \\
\hline Remora albescens & White Suckerfish & pelagic-oceanic & no & 1 & F5 \\
\hline Remora osteochir & Marlin Sucker & pelagic-oceanic & no & 1 & C10 \\
\hline Rhomboplites aurorubens & Vermilion Snapper & Demersal & minor commercial & 1 & C3 \\
\hline Scomberomorus cavalla & King Mackerel & reef-associated & commercial; gamefish & 1 & F8 \\
\hline Scombrinae sp. & Tuna & pelagic-neritic & commercial; gamefish & 1 & F8 \\
\hline Selar crumenophthalmus & Bigeye Scad & reef-associated & commercial; gamefish & 1 & F8 \\
\hline Sparisoma viride & Stoplight Parrotfish & reef-associated & $\begin{array}{l}\text { aquarium; minor } \\
\text { commercial }\end{array}$ & 2 & C14, C6 \\
\hline Syacium papillosum & Dusky Flounder & reef-associated & minor commercial & 2 & F8, C8 \\
\hline $\begin{array}{l}\text { Synodus intermedius/ } \\
\text { S. foetens }\end{array}$ & $\begin{array}{l}\text { Sand Diver/ } \\
\text { Inshore Lizardfish }\end{array}$ & reef-associated & $\begin{array}{l}\text { minor commercial } \\
\text { /subsistence fishery; } \\
\text { gamefish }\end{array}$ & 1 & C10 \\
\hline Synodus synodus & Diamond Lizardfish & reef-associated & commercial & 4 & C8, C7, C10, C11 \\
\hline Taractichthys steindachneri & Sickle Pomfret & benthopelagic & commercial & 1 & F9 \\
\hline Thalassoma bifasciatum & Bluehead Wrasse & reef-associated & aquarium & 3 & C14, C3, C2 \\
\hline Thunnus atlanticus & Blackfin Tuna & pelagic-oceanic & commercial; gamefish & 8 & $\begin{array}{l}\text { F2, F3, F4, F8, F9, } \\
\text { C10, C4, C3 }\end{array}$ \\
\hline $\begin{array}{l}\text { Thunnus atlanticus/ } \\
\text { T. albacares }\end{array}$ & $\begin{array}{l}\text { Blackfin/ } \\
\text { Yellowfin Tuna }\end{array}$ & pelagic-oceanic & commercial; gamefish & 4 & F3, F4, C10, C3 \\
\hline $\begin{array}{l}\text { Thunnus atlanticus/ } \\
\text { T. albacares/T. obesus }\end{array}$ & $\begin{array}{l}\text { Blackfin/Yellowfin/ } \\
\text { Bigeye Tuna }\end{array}$ & pelagic-oceanic & commercial; gamefish & 3 & F2, F3, F8 \\
\hline
\end{tabular}




\begin{tabular}{|c|c|c|c|c|c|}
\hline Taxon & FishBase Common Name & Habitat & Economic Importance & $\begin{array}{l}\text { Encounter } \\
\text { Frequency } \\
\text { (Stations) }\end{array}$ & $\begin{array}{l}\text { Station(s) Eggs } \\
\text { Encountered }\end{array}$ \\
\hline $\begin{array}{l}\text { Thunnus atlanticus/ } \\
\text { T. albacares/T. thynnus/ } \\
\text { T. obesus }\end{array}$ & Tuna & pelagic-oceanic & commercial; gamefish & 1 & F3 \\
\hline $\begin{array}{l}\text { Thunnus atlanticus/ } \\
\text { T. thynnus }\end{array}$ & $\begin{array}{l}\text { Blackfin/ } \\
\text { Bluefin Tuna }\end{array}$ & pelagic-oceanic & commercial; gamefish & 3 & F1, F3, F8 \\
\hline Trachinotus falcatus & Permit & reef-associated & commercial; gamefish & 1 & C3 \\
\hline Xiphias gladius & Swordfish & pelagic-oceanic & commercial; gamefish & 1 & F7 \\
\hline Xyrichtys novacula & Pearly Razorfish & reef-associated & $\begin{array}{l}\text { aquarium; minor } \\
\text { commercial; gamefish }\end{array}$ & 3 & F7 \\
\hline
\end{tabular}

